\title{
ВНЕДРЕНИЕ ИКТ-ТЕХНОЛОГИЙ В ДЕЯТЕЛЬНОСТЬ ДЕТСКОГО ДОМА.
}

\author{
Лукьянова Галина Александровна \\ Студентка 1 курса магистратуры \\ Северного (Арктического) Федерального Университета \\ имени М.В. Ломоносова \\ Высшая школа психологии, педагогики и физической культуры, \\ 2. Архангельск, Российская Федерачия
}

\begin{abstract}
Аннотация. В статье затрагиваются вопросы, которые касаются конкретных способов и методов реализации информационных технологий в процессе организации деятельности воспитательного процесса детского дома.

Abstract. The article deals with issues that relate to specific ways and methods of implementing information technologies in the process of organizing the activities of the educational process of an orphanage.

Ключевые слова: информационные коммуникативные технологии, информатизация, мультимедиа.

Keywords: information and communication technologies, informatization, multimedia.
\end{abstract}

На сегодняшний день одним из важнейших направлений модернизации образования и воспитания в целом является информатизация образования.

Актуальность применения в педагогической практике информационно-коммуникативных технологий сложно переоценить. Это связано, в первую очередь, со стремительным развитием информационного пространства и общества. Равным образом, это связано и с внедрением федеральных государственных стандартов, так как они диктуют современному образованию о изменении и придании интерактивного характера образовательной среде.

Изначально, информационно-коммуникативные технологии открывают огромные перспективы в практической деятельности педагогов в целом. Прежде всего, их преимущество заключается в большем объёме выполняемой работы практически единовременно. Это связано, в первую очередь, с тем, что педагогические работники могут производить синтез и систематизировать теоретический материал по всевозможным направлениям, в зависимости от поставленных целей [7].

Кроме это, применение в практике информационных технологий расширяет для педагогов круг дидактических возможностей, связанных в некоторой мере «оживлением» представляемого материала для подопечных.

Применение информационно-коммуникативных технологий приобретает особую актуальность в условиях воспитания и обучения детей сирот и детей, оставшихся без попечения родителей. Это связано, в первую очередь с особенностями восприятия и мироощущения воспитанников данного учреждения. Дети часто рассеянны и задумчивы, эти качества могут мешать их принимать и обрабатывать важную и необходимую информацию. Исключением может стать лишь информация действительно в интересующей их области. И перед педагогами стоит очень важная и непростая задача - завладеть вниманием детей [2].

Именно внедрение информационных коммуникационных технологий в воспитательный процесс и организацию работы с детьми может способствовать, на наш взгляд, решению задач, связанных с завладением внимания детей, а также расширению методов передачи всевозможной информации и знаний в той или иной области. ИКТ-технологии открывают перед педагогами совершенно новые возможности в области воспитания, обучения, общения и познания мира в целом. Поэтому в данной статье затронем вопросы внедрения ИКТтехнологий в образовательную и воспитательную деятельность детского дома.

К одному из актуальных направлений работы в учреждении детского дома может быть использование мультимедийных технологий. Изучение опыта работы педагогов в данной области показывает, что мультимедийные технологии открывают возможности представления методического развивающего материала при помощи ярких, красочных образов, которые были бы наполнены исчерпывающей структурированной информацией в хронологическом порядке [1,6].

При реализации данного вида ИКТ-технологий у воспитанников задействуются всевозможные каналы восприятия информации, что, в свою очередь, сказывается не только на типичном запоминании тех или иных фактов, но и на развитии ассоциативной функции мозга.

Использование мультимедиа имеет ряд преимуществ над традиционными формами воспитательной и образовательной деятельности, к ним можно отнести:

- демонстрация информации посредством интерактивной доски, экрана монитора или проектора вызывает у детей наибольший интерес, в это же время, наглядность способствует лучшему запоминанию;

- имеется возможность использования таких функций как анимация, видеоизображение и аудиотрансляция;

- занятие с использованием мультимедиа позволяет применять задействовать такие виды деятельности как игровая, учебная и самостоятельная; 
- в целом меняется восприятие и эстетика занятия: педагог имеет мощные рычаги управления внимаем воспитанников [4,8].

При помощи ИКТ сегодня стало возможным проведение контроля знаний обучающихся. Использование нестандартных форм контроля знаний - один из способов формирования положительной мотивации к процессу учения и повышения качества обучения. Применение программы Main Test позволяет провести контроль знаний обучающихся в необычной форме с применением теста, который можно создать самому преподавателю. Использование тестов помогает не только экономить время преподавателя, но и дает возможность обучающимся самим оценить свои знания, свои возможности. Тесты - это задания, состоящие из ряда вопросов и нескольких вариантов ответа на них для выбора в каждом случае одного верного.

С их помощью можно:

- проверить большой объем изученного материала малыми порциями;

- быстро диагностировать овладение учебным материалом большим массивом учащихся.

С целью повышения эффективности учебного процесса актуальность приобретает использование компьютерного тестирования. Данный вид информационно-коммуникативной технологии позволяет организовать быструю обратную связь педагогов с подопечными.

К достоинствам также можно отнести моментальная обработка и выставление отметки за конкретное тестирование. Кроме этого. В данном случае в полной мере исключается вероятность субъективности оценки и в значительной мере экономит временные ресурсы педагогов.

К одним из востребованных и вызывающих интерес детей можно отнести занятия с применением обучающих игровых программ.

При организации такого занятия применяются несколько персональных компьютеров для одновременной работы определенной группы воспитанников. Методом программного обучения в данном случае является обучающая игра, содержащая в себе познавательный учебный материал. Это альтернатива электронного учебника, при работе с которым дети самостоятельно изучают материал, выполняют задания, предложенные в программе. Далее происходит контроль компетентности детей в изучаемой области [5].

Кроме всего вышеизложенного, важно, чтобы занятия отвечали таким требованиям как:

- гендерное и возрастное соответствие;

- занимательность и легкость овладения;

- исследовательский характер;

- разносторонний спектр развиваемых навыков и представлений детей.

Применение таких учебно-развлекательных программ позволяет расширять и углублять знания, овладевать навыками работы с персональным компьютером, но и повышать креативность детей. Использование творческих и познавательных игр создаёт условия для дополнительной мотивации к учебной деятельности. В это же время, работа индивидуальная работа с компьютером способствует самостоятельности детей при решении сложившихся ситуаций $[3,7]$.

Внедрение информационно-коммуникативных технологий имеют ряд преимуществ перед традиционными методами организации учебно-воспитательного процесса:

- обеспечивается наглядность, способствующая наилучшему восприятию и запоминанию материала;

- представляется возможность расширения эксплуатации технических средств обучения и воспитания;

- расширяются возможности демонстрации процессов в мире, наблюдение за которыми невозможно без применения информационных технологий;

- побуждение детей к поисковой исследовательской деятельности;

- и наконец, информационно-коммуникативные технологии открывают дополнительные возможности с особыми детьми, в нашем случае это дети-сироты и дети, оставшиеся без попечения родителей. Например, появляется возможность индивидуального обучения, реализация личностно-ориентированного и дифференцированного подхода к обучению и воспитанию.

Список использованной литературы:

анильчук, Е.В. Методологические предпосылки и сущностные характеристики информационной культуры педагога [Текст] - Е.В. Данильчук // Педагогика. - 2003. - № 2;

ахарова, Н.И. Внедрение информационных технологий в учебный процесс [Текст] - Н.И. Захарова // Начальная школа. - 2008. №1. - С. 31- 33;

3. Концепция модернизации образования [Электронный ресурс]. - Режим доступа: http://static.government.ru/media/files/mlorxfXbbCk.pdf;

4. Кузнецов, А.А. Информационно-коммуникационная компетентность современного учителя [Текст] А.А. Кузнецов // Информатика и образование. - 2010. - № 4;

5. Кукушкина, О.И. Компьютерные технологии в контексте профессии: обучение студентов [Текст] / О.И. Кукушкина // Дефектология - М., 2001. - № 3; 
6. Матрос, Д.Ш. Внедрение информационных и коммуникационных технологий в школу [Текст] / Д.Ш. Матрос // Информатика и образование. - 2000. - № 8;

7. Можаева, Г.Н., Лукиных, Т.Н. Информационные революции и их роль в развитии общества // [Электронный pecypc]. - Режим доступа: http://huminf.tsu.ru (дата обращения 26.01.2021). - Загл. с экрана.

едеральный государственный образовательный стандарт общего образования (утв. Приказом Минобрнауки России № 1155 от 17 октября 2013 г. «Об утверждении федерального государственного образовательного стандарта дошкольного образования» 